\title{
舌下免疫療法のadverse effects（アナフィラキシー対策）
}

\author{
中 村 陽一 \\ 横浜市立みなと赤十字病院アレルギーセンター
}

舌下免疫療法（SLIT）で起こるadverse effectsのほと んどは, 苦み, 口腔内掻痒, 咽頭刺激感などの局所症状 や軽度の消化器症状であり, SLITの大規模試験でも, 皮 下注射の免疫療法 (SCIT) で見られるような全身症状は 起こらなかったと報告されている。しかし，頻度は低い ながらSLITによるアナフィラキシーは存在し, 複合抗原 やダニ抗原によるSLIT維持療法中の呼吸困難やショッ ク，花粉抗原の初回投与時に起こった喘息発作などが報 告されている。これらの症例に共通するのは気管支喘息 の合併であり, $\beta$ ブロッカーの使用と共に重要なアナ フィラキシーの危険因子と考えられる。アナフィラキ シーは「急速に発現し, 死に至ることのある重篤なアレ ルギー反応」であり, 即座の診断と対応が必要となる。 World Allergy Organizationが問診内容や特徵的な症状

表 1 アナフィラキシーの診断のための臨床判断基準 職業性アレルギー疾患ガイドライン 2013 (協和企画) より引用 以下の 3 つの基準のうち, 1 つ以上を満たす場合にアナフィラ キシーである確率が高い。

1. 数分から数時間で突然発症する皮膚症状 (全身莖麻疹, 瘙 痒あるいは紅潮）や粘膜症状（口唇・舌・口蓋垂の腫脹） のいずれかまたは両方に加えて下記の合併 呼吸器症状（呼吸困難, 喘鳴, 低酸素血症など) 血圧低下・末梢循環不全症状 (脱力, 意識障害, 失禁)

2.アレルゲンあるいはその他（非IgE機序のアレルゲンある いは非アレルギー性のマスト細胞刺激因子) への曝露後に 数分から数時間で突然発症する下記 2 つ以上の症状

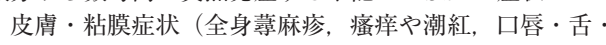
口蓋垂の腫脹)

呼吸器症状（呼吸困難, 喘鳴, 低酸素血症など) 血圧低下・末梢循環不全症状 (脱力, 意識障害, 失禁) 持続する胃腸症状（痤攣性の腹痛・嘔吐）

3. 既知のアレルゲンへの曝露と考えられるエピソード (ハチ などの刺傷や特異的免疫療法の注射など) 後に数分から数 時間で起こる血圧低下

乳幼児・小児の場合は, 収縮期血圧が年齢を考慮しても 異常な程度に*, あるいは平常時の $70 \%$ 未満に低下 成人の場合は, 収縮期血圧が $90 \mathrm{mmHg}$ 未満, あるいは平 常時の $70 \%$ 未満に低下

*異常な低血圧とは, 生後 1 か月〜 1歳では $70 \mathrm{mmHg}$ 未満, 1 10歳ま では $(70 \mathrm{mmHg}+2 \times$ 年齢) 未満, $11 \sim 17$ 歳は $90 \mathrm{mmHg}$ 未満, 正常心 拍数とは, $1 \sim 2$ 歳は80 1 140 回/分, 3 歳は80 120回/分, 4 歳以 上は70 115回/分。なお，乳幼児では，血圧低下やショックよりも 呼吸困難が起こりやすく, 頻脈がショックの前兆として有用な指標と なる。
に基づく臨床判断基準（表1）を示しているが,一般的に は, 数分から数時間で起こる，(1)皮膚あるいは粘膜症状 （全身の尋麻疹，瘙痒，紅潮，口唇，舌，口蓋垂の腫脹） に加えて, (2)呼吸器症状 (呼吸困難, 喘鳴, 低酸素血症), 血圧低下による症状 (失神, 意識消失, 失禁), 持続する 消化器症状（嘔吐, 㽷攣性腹痛）のうちの少なくとも一 つが合併する場合にアナフィラキシーを疑う。アナフィ ラキシーの疑いがあるなら, エピネフリンの筋肉注射, 酸素投与, 補液投与を開始する (表2)。エピネフリンは 気道閉塞や血圧低下を抑制することにより生命の危機的 な状況を是正する。SLITを初めとするアレルゲン免疫療 法の実施に際しては，普段からのアナフィラキシーに対 する救急体制の整備と共に, 初回導入時の薬剤投与後 1 時 間程度の観察が必要である。

表 2 アナフィラキシーの急性期治療

職業性アレルギー疾患ガイドライン 2013 (協和企画) より引用 最初に実施すべき項目

1 ) アナフィラキシーを認識し治療するための文書化された緊 急時用プロトコールを携帯し習熟する。

2）誘発因子が分かれば除去する（例えば, 静脈内投与中の造 影剤や薬物が疑わしいなら中止する。

3 ) 救命救急の基本的評価（循環・気道・呼吸・意識障害 · 皮 膚兆候・体重など）を行う。

速やかに実施すべき処置

4) 助けを呼ぶ (院内なら蘇生チーム, 院外なら救急隊)。

5 ）アナフィラキシーと判断すれば，大腿部中央の前外側に $0.1 \%$ アドレナリンの筋注 $(0.01 \mathrm{mg} / \mathrm{kg}$, 最大容量は成人 $0.5 \mathrm{mg}$ ，小児 $0.3 \mathrm{mg}$ )

実施時刻を記録し，必要に応じて 5 ～15分毎に繰り返す。 通常は $1 \sim 2$ 回で奏効する。

6 ）患者を仰臥位, あるいは呼吸困難や嘔吐があればそれらに 応じた体位にする。下肢を挙上させる。急激な起立や座位 は避ける。

必要に応じて実施すべき処置

7 ) フェイスマスクが経鼻エアウェイによる高流量（6～81） 分）の酸素投与を行う。

8 ）血管針あるいはカテーテル（内径14～16G）で血管確保し, 生理食塩水を $1 \sim 2 L$ 点滴静注する（最初の $5 \sim 10$ 分で成人 は5〜 10mL/ kg，小児は $10 \mathrm{~mL} / \mathrm{kg}$ )

9 ）必要に応じて胸部圧迫法で心肺蘇生を行う。

状況評価の継続

10）頻回かつ定期的に, 血圧 - 心拍数 - 呼吸状態 - 酸素化を評 価する。可能なら呼吸心拍装置でモニターする。 